\title{
First Record of Two Euplotes Ciliates (Ciliophora: Spirotrichea: Euplotida) from Korea
}

\author{
Mi-Hyun Park ${ }^{1}$, Se-Joo Kim ${ }^{1,2}$ and Gi-Sik Min ${ }^{1, *}$ \\ ${ }^{1}$ Department of Biological Sciences, Inha University, Incheon 402-751, Korea \\ ${ }^{2}$ The Research Institute for Natural Sciences, Hanyang University, Seoul 133-791, Korea
}

\begin{abstract}
Two marine euplotid ciliates, i.e. Euplotes cristatus Kahl, 1932 and E. minuta Yocom, 1930, were collected from the public waterfront of Incheon on the Yellow Sea and from the Songjeong Beach, Busan, in the Strait of Korea, respectively. These two species were verified as unrecorded species in Korea. These species were described based on live observation, protargol impregnation, and silver nitrate impregnation. In addition, the small subunit ribosomal DNA (SSU rDNA) sequences of the two species were compared with previously known sequences of the Euplotes species. Euplotes cristatus has an elongated oval form, size in vivo of $60-84 \times 38$ $68 \mu \mathrm{m}, 35-50$ adoral zone of membranelles (AZM), 10 frontoventral cirri (FVC), 5 transverse cirri (TC), 4-5 caudal cirri (CC), 8 dorsal kineties (DK), 10-16 dorsal cilia of middle DK, and silverline system of single-vannus type. Euplotes minuta has a small ovoid form (44-53×26-35 $\mu \mathrm{m}$ in vivo), 31-41 AZM, 10 FVC, 5 TC, 4 CC, 9 DK, 10-12 dorsal cilia of middle DK, and silverline system of single-vannus type.
\end{abstract}

Keywords: Euplotes cristatus, Euplotes minuta, marine euplotid ciliate, SSU rDNA, Korea

\section{INTRODUCTION}

Species in the genus Euplotes Ehrenberg, 1830 have been known as easily investigated and cultured ciliates in the aquatic ecosystem (Petroni et al., 2002; Schwarz et al., 2007). Over 100 species have been described in this genus from the world (Berger, 2001). After the pattern of the silverline system came to be considered as an important factor for species classification, many elements on the classification of the euplotid species have been newly revised by taxonomists (Tuffrau, 1960; Borror, 1968, 1972; Carter, 1972; Curds, 1974; Gates, 1978).

The morphological characters of Euplotes-complex are still disputed. Curds (1975) partitioned the Euplotes-complex species into six species groups based on differences in the dargyrome pattern. Gates and Curds (1979) newly divided this species complex into three groups characterized as single-, double-, and multiple- dargyrome types. More recently, Borror and Hill (1995) redefined the Euplotes-complex species into four genera (Euplotes, Euplotopsis, Euplotoides, and Moneuplotes) following characteristics of cortical structure, endosymbionts, morphometric data, morphogenetic patterns, and ecology. Yi et al. (2009) suggested that the systematics of the Euplotes-complex needs be reconsidered based on molecular evidence in some cases of taxonomic

\section{*To whom correspondence should be addressed}

Tel: 82-32-860-7692, Fax: 82-32-874-6737

E-mail: mingisik@inha.ac.kr classification.

To date, eight species of Euplotes have been reported in Korea: E. aediculatus, E. charon, E. eurystomus, E. muscicola, E. muscorum, E. parawoodruffi, E. patella, and E. vannus (Shin and Kim, 1988; Shin et al., 1992; Shin and Kim, 1995; Jo and Shin, 2003; Kwon and Shin, 2006; Kwon et al., 2007).

Two species, Euplotes cristatus and E. minuta, are firstly reported to Korean fauna. Two species are described based on their living morphology, protargol impregnation, silver nitrate impregnation, and analysis of small subunit ribosomal RNA (SSU rRNA) gene sequences.

\section{MATERIALS AND METHODS}

\section{Collection and identification}

Euplotes cristatus and E. minuta were collected from coastal areas of Korea using both of PEFS (the polyurethane foam enveloped) system (Xu et al., 2009) and natural slides (Kim and Min, 2009b). Rice grains were used to enrich bacterial growth in the cultures. The specimens were observed under the light microscope (Leica DM2500). The infraciliature was impregnated with the protocol of Foissner (1991). The Chatton-Lwoff method was used for revealing the silverline systems (Corliss, 1953; Song and Wilbert, 1997). Counts and measurement on stained specimens were performed at 1,000 magnification, and drawings were made with a camera 
lucida. The classification scheme followed Lynn and Small (2002). Terminology is mainly according to Curds (1975) and Song et al. (2009). Abbreviations were AZM, adoral zone of membranelles; $\mathrm{CC}$, caudal cirri; $\mathrm{CV}$, contractile vacuole; DK, dorsolateral kineties; FVC, frontoventral cirri; Ma, macronuclear nodule; Mi, micronucleus; PM, paroral membrane; TC, transverse cirri.

\section{Molecular identification}

Single living individual specimens were isolated under a dissecting microscope (Olympus SZX12) and washed five times in sterile seawater of the appropriate salinity and then transferred into $1.5 \mathrm{~mL}$ microcentrifuge tubes. Genomic DNA extraction was carried out using RED Extract-NAmp $^{\mathrm{TM}}$ Tissue PCR kit (Sigma-Aldrich). Amplification of SSU rRNA gene and sequencing of the purified PCR products were performed according to Kim and Min (2009a). Sequencing was carried out using an ABI PRISM ${ }^{\circledR} 3700$ DNA Analyzer (Applied Biosystems) using a Dye Terminator Cycle Sequencing Ready Reaction Kit (Applied Biosystems). Sequence variations among the species were calculated using MEGA4 software (Tamura et al., 2007) with a Kimura 2-parameter.

\section{SYSTEMATIC ACCOUNTS}

\author{
Phylum Ciliophora Doflein, 1901 \\ Class Spirotrichea Bütschli, 1889 \\ Subclass Hypotrichia Stein, 1859 \\ Order Euplotida Small \& Lynn, 1985 \\ Family Euplotidae Ehrenberg, 1838 \\ Genus Euplotes Ehrenberg, 1830
}

$1 *$ Euplotes cristatus Kahl, 1932 (Fig. 1 and Table 1)

Euplotes cristatus Kahl, 1932, p. 633, Figs. S. 638, 20-21;

Tuffrau, 1960, p. 37, Figs. 20-21; Carter, 1972, p. 468,

Figs. 1-2; Curds, 1975, p. 12, Fig. 5; Carey, 1992, p. 206,

Fig. 819.

Moneuplotes cristatus (Kahl, 1932) Borror and Hill, 1995, p. 461.

Material examined. Specimens were collected from the public waterfront, Incheon $\left(37^{\circ} 26^{\prime} \mathrm{N}\right.$ and $\left.126^{\circ} 35^{\prime} \mathrm{E}\right)$ on the Yellow Sea of Korea on May 21-29, $2007\left(18^{\circ} \mathrm{C}, \mathrm{ca} .29 \%\right.$, and $\mathrm{pH}$ ca. 7.8).

Description. Cell size in vivo $60-84 \times 38-68 \mu \mathrm{m}$ in length; body shape constant, elongate oval as shown in Fig. 1A, E$\mathrm{F}$; anterior end narrowly rounded while posterior end widely rounded; dorso-ventrally flattened (Fig. 1H-I); buccal field narrow, extending about $67 \%$ of body length (Fig. 1A-B, E, J). Cytoplasm hyaline, central part opaque due to numerous yellow to green-coloured and different-sized lipid droplets and a few food vacuoles and granules (Fig. 1A, E-J). CV adjacent to the rightmost TC, about $7 \mu \mathrm{m}$ in diameter (Fig. $1 \mathrm{~J}$, arrowhead).

Ma curved C-shaped, containing numerous large nucleoli; one spherical Mi located on the upper left border of the Ma (Fig. 1B, M-N).

Infraciliature as shown in Fig. 1A-C, F-G, J, M, O. Consistently $10 \mathrm{FVC}$ arranged in normal pattern and located on anterior ventral surface (Fig. 1A-C, M, O); 5 strong TC positioned at posterior region (Fig. 1A-C, E); 4 to $5 \mathrm{CC}$ present at posterior end (Fig. 1A-C, F, M; 1F, arrowheads). AZM prominent, proximal portion curved at about $90^{\circ}$ in direction of right, and composed of 35-50 membranelles ( $c a .15 \mu \mathrm{m}$ in length) (Fig. 1B, F-G, J). PM small, beneath buccal lip (Fig. 1B, J; 1J, arrow).

Dorsal surface detected ridges (Fig. 1K, arrowheads). DK distinct, 8 in number, extending of body length; 6 DK located on dorsal side and each one DK located on both margins of ventral surface (Fig. 1B, D, L, M-N, P; 1L, arrowheads); composing about 10-16 dikinetids in middle DK (Fig. 1D). Silverline system typical vannus type, single-type dargyrome, irregular pattern on ventral side (Fig. 1C-D, O-P).

The SSU rDNA sequence of this population is $1,856 \mathrm{bp}$ in length, and deposited in GenBank accession number GU953667. Inter-specific variation is $0.8 \%$ and $1.8 \%$ between this population and two other species, E. minuta (AJ305244-6 and EF094958) and known E. vannus (AY361854, AY361856, and AJ305241), respectively.

Distribution. France, Germany, USA, and Korea (this study). Remarks. Euplotes cristatus was originally described by Kahl (1932) based on living observation. However in this original description, the important information for species identification such as the exact cirral pattern (number of AZM, FVC, TC, DK, and dikinetids of mid-DK) and silverline system was not provided. Later, Tuffrau (1960) redescribed their population using the Chatton-Lwoff staining method (Chatton and Lwoff, 1930, 1935). The description of the present population is almost identical to that of Tuffrau's (1960) population in size of body (55-75 $\mu \mathrm{m}$ in long, size strongly overlapped); number of FVC (10), TC (5), DK (8); type of dargyrome (single-vannus) with exception of shape of body; number of AZM, CC, and cilia of mid-DK. Tuffrau (1960) noted the form of body, clearly ovoid, while this population has an elongated oval form. Tuffrau (1960) did not describe the number of AZM and dikinetids of mid-

\footnotetext{
1*벼슬머리자라하모충 (신칭)
} 

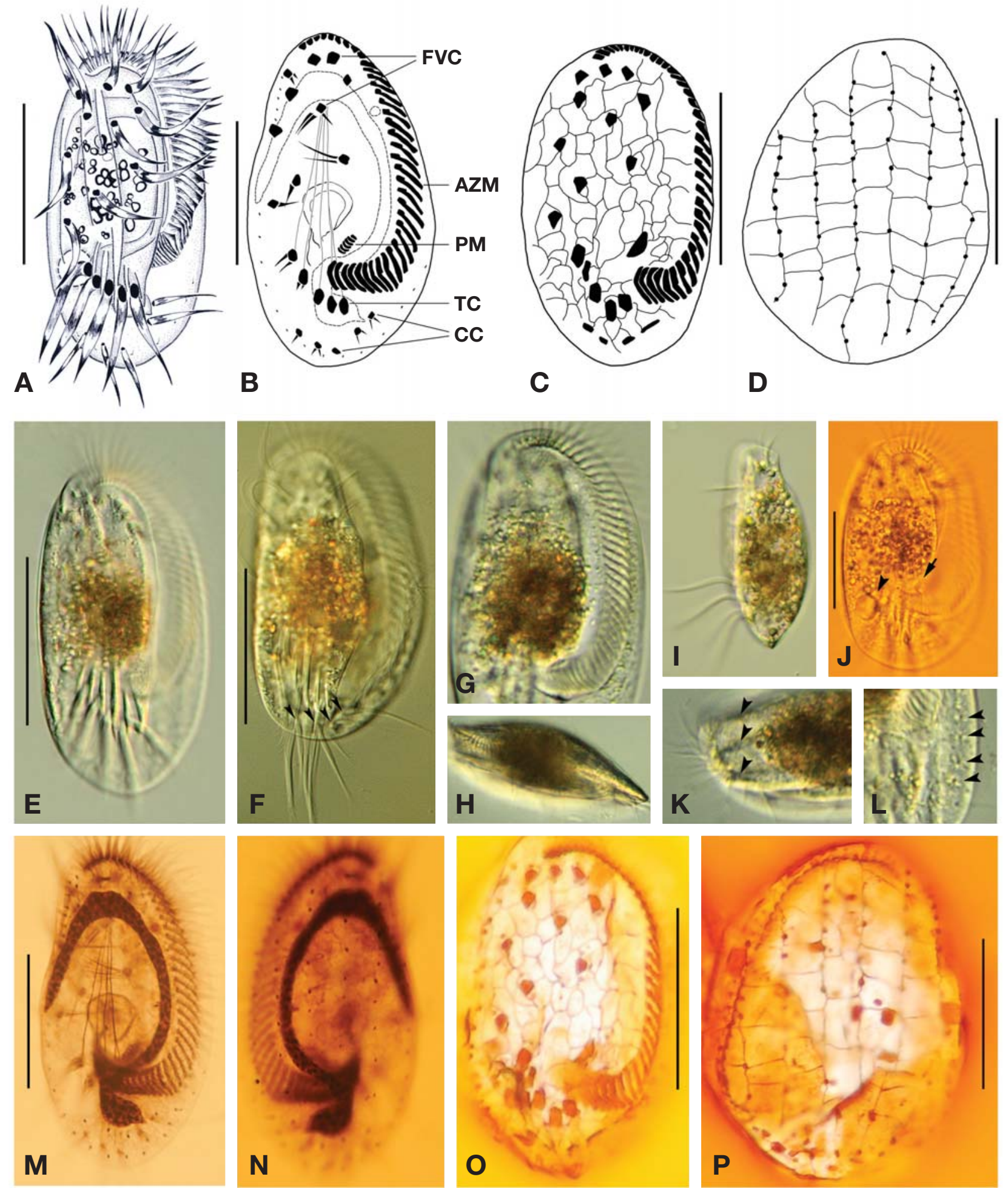

Fig. 1. Morphology and infraciliature of Euplotes cristatus Kahl, 1932 in vivo (A, E-L), protargol impregnation (B, M-N), and silver nitrate impregnation (C-D, O-P). A, E-F, ventral view of live, arrowheads to show caudal cirri (F); $B$, infraciliature of ventral side; C$D, O-P$, silverline system on ventral $(C, O)$ and dorsal $(D, P)$ sides; $G$, adoral zone of membranelles of live; $H-I$, lateral view of live; $\mathrm{J}$, ventral view of live, note contractile vacuole (arrowhead) and paroral membrane (arrow); K, dorsal view, to show the dorsal ridges (arrowheads); L, detailed view to show the dorsolateral cilia (arrowheads); M-N, ventral (M) and dorsal (N) sides of protargol impregnation. Scale bars $=30 \mu \mathrm{m}$. 
Table 1. Morphometric data of Euplotes cristatus (upper row) and E. minuta (lower row). Data are based on protargol impregnated specimens. Abbreviations are described in the text.

\begin{tabular}{|c|c|c|c|c|c|c|c|}
\hline Characteristics & Min. & Max. & Mean & SD & SE & CV & $\mathrm{n}$ \\
\hline Body length & $\begin{array}{l}65.6 \\
40\end{array}$ & $\begin{array}{l}84.8 \\
52.5\end{array}$ & $\begin{array}{l}75.52 \\
45.5\end{array}$ & $\begin{array}{l}5.65 \\
3.77\end{array}$ & $\begin{array}{l}1.26 \\
0.84\end{array}$ & $\begin{array}{l}7.49 \\
8.29\end{array}$ & $\begin{array}{l}20 \\
20\end{array}$ \\
\hline Body width & $\begin{array}{l}30.4 \\
22.5\end{array}$ & $\begin{array}{l}51.2 \\
37.5\end{array}$ & $\begin{array}{l}42.08 \\
30.44\end{array}$ & $\begin{array}{l}5.52 \\
3.42\end{array}$ & $\begin{array}{l}1.23 \\
0.77\end{array}$ & $\begin{array}{l}13.12 \\
11.25\end{array}$ & $\begin{array}{l}20 \\
20\end{array}$ \\
\hline Number of AZM & $\begin{array}{l}35 \\
31\end{array}$ & $\begin{array}{l}50 \\
41\end{array}$ & $\begin{array}{l}43.65 \\
36.15\end{array}$ & $\begin{array}{l}3.86 \\
3.54\end{array}$ & $\begin{array}{l}0.86 \\
0.79\end{array}$ & $\begin{array}{l}8.84 \\
9.8\end{array}$ & $\begin{array}{l}20 \\
20\end{array}$ \\
\hline Number of FVC & $\begin{array}{l}10 \\
10\end{array}$ & $\begin{array}{l}10 \\
10\end{array}$ & $\begin{array}{l}10 \\
10\end{array}$ & $\begin{array}{l}0 \\
0\end{array}$ & $\begin{array}{l}0 \\
0\end{array}$ & $\begin{array}{l}0 \\
0\end{array}$ & $\begin{array}{l}20 \\
20\end{array}$ \\
\hline Number of TC & $\begin{array}{l}5 \\
5\end{array}$ & $\begin{array}{l}5 \\
5\end{array}$ & $\begin{array}{l}5 \\
5\end{array}$ & $\begin{array}{l}0 \\
0\end{array}$ & $\begin{array}{l}0 \\
0\end{array}$ & $\begin{array}{l}0 \\
0\end{array}$ & $\begin{array}{l}20 \\
20\end{array}$ \\
\hline Number of $\mathrm{CC}$ & $\begin{array}{l}4 \\
4\end{array}$ & $\begin{array}{l}5 \\
4\end{array}$ & $\begin{array}{l}4.45 \\
4\end{array}$ & $\begin{array}{c}0.51 \\
0\end{array}$ & $\begin{array}{c}0.11 \\
0\end{array}$ & $\begin{array}{c}11.47 \\
0\end{array}$ & $\begin{array}{l}20 \\
20\end{array}$ \\
\hline Number of DK & $\begin{array}{l}8 \\
9\end{array}$ & $\begin{array}{l}8 \\
9\end{array}$ & $\begin{array}{l}8 \\
9\end{array}$ & $\begin{array}{l}0 \\
0\end{array}$ & $\begin{array}{l}0 \\
0\end{array}$ & $\begin{array}{l}0 \\
0\end{array}$ & $\begin{array}{l}20 \\
20\end{array}$ \\
\hline Number of dikinetids in middle DK (no. 4) & $\begin{array}{c}10 \\
-\end{array}$ & $\begin{array}{c}16 \\
-\end{array}$ & $\begin{array}{c}12.75 \\
-\end{array}$ & $\begin{array}{c}1.68 \\
-\end{array}$ & $\begin{array}{c}0.38 \\
-\end{array}$ & $\begin{array}{c}13.19 \\
-\end{array}$ & $\begin{array}{c}20 \\
-\end{array}$ \\
\hline Number of dikinetids in middle DK (no. 5) & $\begin{array}{r}9 \\
10\end{array}$ & $\begin{array}{l}14 \\
12\end{array}$ & $\begin{array}{l}12.15 \\
10.55\end{array}$ & $\begin{array}{l}1.35 \\
0.69\end{array}$ & $\begin{array}{l}0.30 \\
0.15\end{array}$ & $\begin{array}{r}11.1 \\
6.5\end{array}$ & $\begin{array}{l}20 \\
20\end{array}$ \\
\hline
\end{tabular}

All measurements in $\mu \mathrm{m}$. Abbreviations not described in the text are as follows: CV, coefficient of variation in \%; Max., maximum; Min., minimum; $\mathrm{n}$, sample size; SD, standard deviation; SE, standard error of mean.

DK, while specimens of this description have 35-50 AZM and 10-16 dikinetids of mid-DK in number, similar to the results of other previous studies (Carter, 1972; Curds, 1975; Carey, 1992). This population has a more variable number of CC (4-5), whereas the other previous studies described only 3 CC (Kahl, 1932) or 4 CC (Tuffrau, 1960; Carter, 1972; Curds, 1975; Carey, 1992).

Euplotes cristatus is morphologically similar to E. vannus and E. minuta and all these three species have dorsal silverline system of single-vannus type. Euplotes vannus (Kwon, et al., 2007) has a larger size of body $(94-111 \times 53-75 v s$. $60-84 \times 38-68 \mu \mathrm{m})$; a higher number of AZM (57-74 vs. 3550), CC (4-7 vs. 4-5), DK (9-10 vs. 8), and dikinetids of midDK (15-22 vs. 10-16) than E. cristatus of this population. Euplotes minuta has a smaller size of body (44-53 × 26-35 $\mu \mathrm{m})$; a higher number of DK (9); and a lower number of AZM (31-41) than E. cristatus of the present population.

$1 *$ Euplotes minuta Yocom, 1930 (Fig. 2 and Table 1, 2) Euplotes minuta Yocom, 1930, p. 242, Figs. 1-2; Borror, 1962, p. 271, Figs. 1-4; Katter, 1970, p. 185, Fig. 31; Curds, 1975, p. 13, Fig. 6; Carey, 1992, p. 207, Fig. 828; Song and Wilbert, 1997, p. 431, Fig. 11.

Moneuplotes minuta (Kahl, 1932) Borror and Hill, 1995, p. 461.
Material examined. Specimens were collected from Songjeong Beach, Busan $\left(35^{\circ} 10^{\prime} \mathrm{N}\right.$ and $\left.129^{\circ} 12^{\prime} \mathrm{E}\right)$ on the Strait of Korea on December 17, $2007\left(18.5^{\circ} \mathrm{C}\right.$, ca. $28.8 \%$, and $\mathrm{pH}$ ca. 8.7).

Description. Cell size in vivo $44-53 \times 26-35 \mu \mathrm{m}$ in length; small and generally oval-outlined, as shown in Fig. 2A-F, $\mathrm{K}-\mathrm{N}$; the right margin is slightly convex to nearly straight, the left margin is more convex (Fig. 2A, E-F); both ends are rounded; dorso-ventrally highly flattened with dorsal side slightly arched while the ventral side is concave. Buccal field approximately $3 / 4$ of body length (Fig. 2A, E-F). Cytoplasm hyaline, containing some shining globules and food (Fig. 2E, F). CV posterior to the rightmost TC, ca. $6 \mu \mathrm{m}$ in diameter (Fig. 2H, arrow).

Ma C-shaped, containing numerous large nucleoli (Fig. 2A-B, I, K-L; I, arrow); Mi spherical.

Ventral surface exhibits most of diagnostic features. AZM prominent, composed of 31-41 membranelles, about $10 \mu \mathrm{m}$ in length (Fig. 2B-C, K, M). PM small, beneath cytoplasmic lip (Fig. 2B). Cirral pattern rather stable, FVC 10 in number, enlarged, positioned at anterior ventral surface; 5 TC and 4 CC located at posterior part (Fig. 2A-C, K, M).

On dorsal surface, ellipsoid formed granules are packed together around the dorsal cilia beneath pellicle in a flowerpattern (Fig. 2G-H; 2H, arrowheads). Nine DK extend entire length of cell (Fig. 2J, arrowheads), 7 DK located on dorsal

\footnotetext{
$1 *$ 작은자라하모충 (신칭)
} 

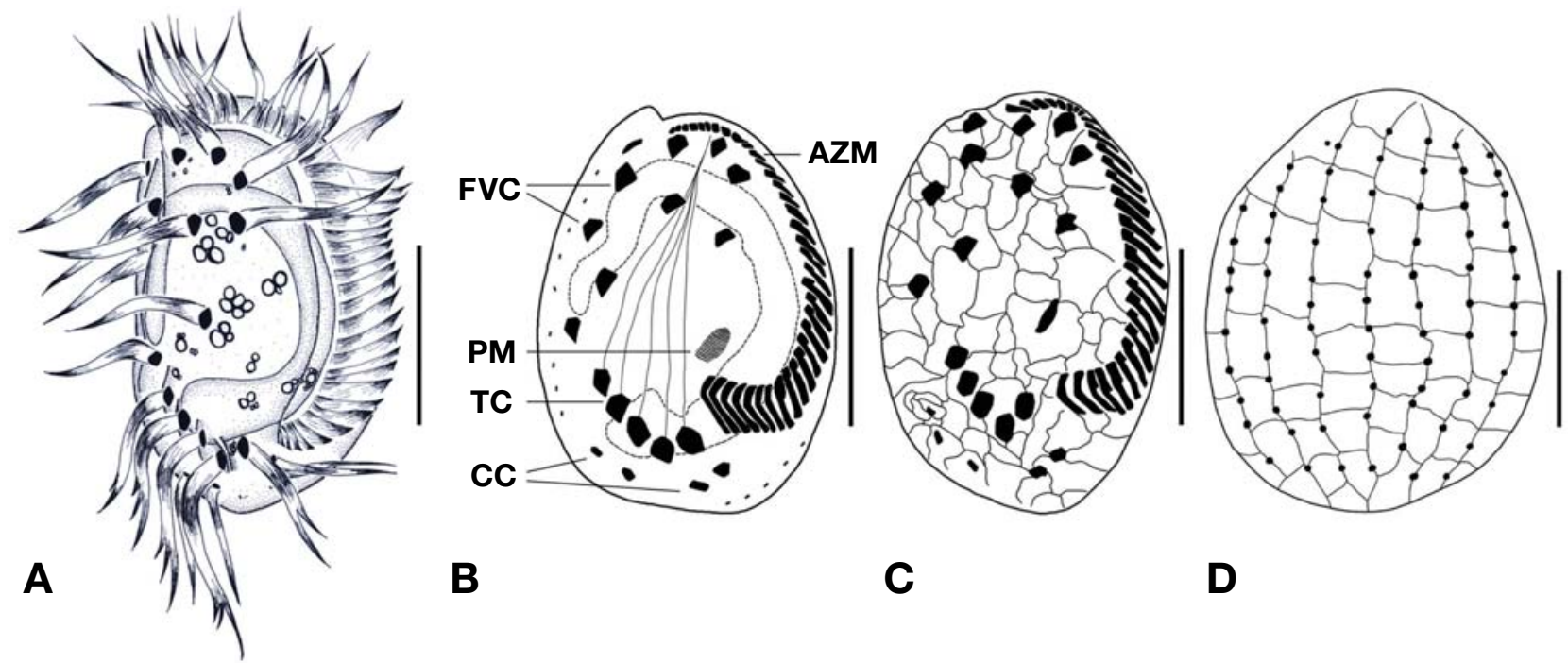

B

C

D
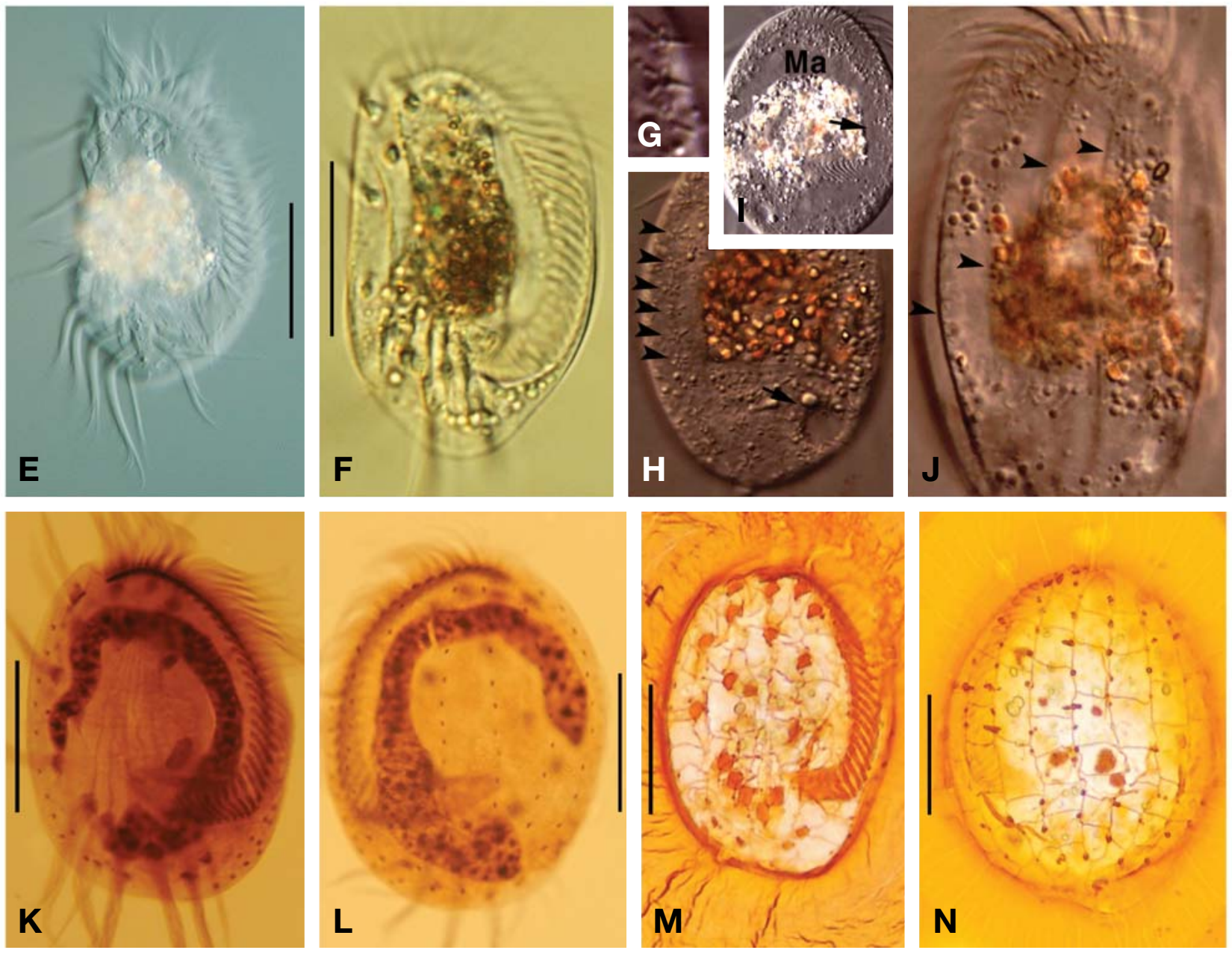

Fig. 2. Morphology and infraciliature of Euplotes minuta Yocom, 1930 in vivo (A, E-J), protargol impregnation (B, K-L), and silver nitrate impregnation (C-D, M-N). A, E-F, ventral view of live; $B$, infraciliature of ventral side; $C-D, M-N$, silverline system on ventral $(C, M)$ and dorsalv $(D, N)$ sides; $-H$, detailed view to show the dorsolateral cilia ( $\mathrm{H}$, arrowheads); I, macronucleus of live (Ma, arrow); J, dorsal view, to show the dorsal ridges (arrowheads); K-L, ventral $(\mathrm{K})$ and dorsal $(\mathrm{L})$ sides of protargol impregnation. Scale bars $=20$ $\mu \mathrm{m}$. 
Table 2. Morphological and morphometric comparison of Euplotes minuta in present and previous descriptions. The abbreviations in the table are the same as those in the text.

\begin{tabular}{|c|c|c|c|c|c|}
\hline Characters & $\begin{array}{l}\text { E. minuta sensu } \\
\text { this study }\end{array}$ & $\begin{array}{c}\text { E. minuta } \\
\text { Yocom, } 1930\end{array}$ & $\begin{array}{l}\text { E. minuta sensu } \\
\text { Borror, } 1962\end{array}$ & $\begin{array}{l}\text { E. minuta sensu } \\
\text { Curds, } 1975\end{array}$ & $\begin{array}{c}\text { E. minuta sensu } \\
\text { Song and Wilbert, } 1997\end{array}$ \\
\hline Body length in vivo & $44-53$ & $44-55$ & $44-64$ & 54 & $50-70$ \\
\hline Body width in vivo & $26-35$ & $27-32$ & $25-31$ & 28 & $40-55$ \\
\hline Body shape & $\begin{array}{l}\text { small and oval, } \\
\text { left margin } \\
\text { more convex }\end{array}$ & $\begin{array}{l}\text { oval, left } \\
\text { edge more } \\
\text { convex }\end{array}$ & $\begin{array}{l}\text { left margin } \\
\text { more convex }\end{array}$ & $\begin{array}{l}\text { oval, right margin } \\
\text { almost straight }\end{array}$ & $\begin{array}{l}\text { elongated oval, } \\
\text { left margin } \\
\text { more convex }\end{array}$ \\
\hline Number of AZM & $31-41$ & - & $31-40$ & $30-40$ & $33-41$ \\
\hline Number of CC & 4 & $4-5$ & 4 & 4 & 4 \\
\hline Number of DK & 9 & - & 9 & 9 & $7-9$ \\
\hline Number of dikinetids in middle DK & $10-12$ & - & - & $12-13$ & $9-11$ \\
\hline Number of dikinetids in leftmost DK & 5 & - & $7-10$ & - & $5-6$ \\
\hline Ma feature & C-shaped & G-shaped & G-shaped & C-shaped & C-shaped \\
\hline
\end{tabular}

All measurements of length and width $=\mu \mathrm{m}$.

side and each one DK located on both margins of ventral surface (Fig. 2B, D, K, L); middle DK with about 10-12 dikinetids; leftmost kinety containing only about 5 dikinetids (Fig. 2B). Silverline system typical vannus type, single-type dargyrome, irregular pattern on ventral side (Fig. 2C-D, M-N).

The SSU rDNA sequence of this population is identical for known E. minuta (AJ305244-6 and EF094958), 1,856 bp in length, and deposited in GenBank accession number GU953668. Inter-specific variation is $1.8 \%$ and $2.0 \%$ between this population and two other species, E. cristatus (GU953667, this study) and known E. vannus (AY361854, AY361856, and AJ305241), respectively.

Distribution. Brasil, China, Italy, USA, and Korea (this study).

Remarks. The population of this study corresponds well with the description in the Yocom (1930) and in the later studies (Borror, 1962; Curds, 1975; Song and Wilbert, 1997). The characteristics of Euplotes minuta populations were compared and summarized with those of previous investigations (Table 2). The present population is very similar to that of Curds (1975) in most aspects, such as size and shape of body; number of AZM, CC, DK, and cilia in mid-DK; and Ma feature. These specimens differ only slightly from those of other previous studies, as follows: 1) Yocom (1930) described 4-5 CC in number and Ma G-shaped while this population is $4 \mathrm{CC}$ in number and $\mathrm{Ma} \mathrm{C}$-shaped in this investigation; 2) Borror's (1962) specimens have a higher number of cilia in leftmost DK (7-10 vs. 5) and different shapes of Ma(G-shape vs. C-shape) than the present specimens. 3) Song and Wilbert's (1997) population has a larger size of body $(50-70 \times$ 40-55 vs. 44-53 $\times 26-35 \mu \mathrm{m})$ and a more variable number of DK (7-9 vs. 9) than this population.

The most closely related species to this species is $E$. van- nus (Muller, 1786). However E. minuta has some remarkable differences from E. vannus (Kwon et al., 2007), such as the body size $(44-53 \times 26-35 v s$. $94-111 \times 53-75 \mu \mathrm{m})$; number of AZM (31-41 vs. 57-74), CC (4 vs. 4-7), DK (9 vs. 9-10), and dorsal cilia of mid-DK (10-16 vs. 15-22).

\section{ACKNOWLEDGEMENTS}

This work was supported partially by grants from the Korea Research Foundation Grant (KRF-2007-C00265), the Ministry of Environment of the Korean Government (NIBR 0741800-1844-326-260-00), and the Eco-technopia 21 project.

\section{REFERENCES}

Berger, H., 2001. Catalogue of ciliate names 1. hypotrichs. Verlag Helmut Berger, Salzburg, p. 206.

Borror, A.C., 1962. Euplotes minuta Yocom (Ciliophora, Hypotrichida). J. Protozool., 9: 271-273.

Borror, A.C., 1968. Systematics of Euplotes (Ciliophora, Hypotrichida); toward union of the old and the new. J. Protozool., 15: 802-808.

Borror, A.C., 1972. Revision of the order Hypotrichida (Ciliophora, Protozoa). J. Protozool., 19: 1-23.

Borror, A.C. and B.F. Hill, 1995. The order Euplotida (Ciliophora): taxonomy, with division of Euplotes into several genera. J. Eukaryot. Microbiol., 42: 457-466.

Carey, P.G., 1992. Marine interstitial ciliates. An illustrated key. Chapman \& Hall, London New York Tokyo Melbourne Madras, p. 351.

Carter, H.P., 1972. Infraciliature of eleven species of the genus Euplotes. Trans. Am. Microsc. Soc., 91: 466-492.

Chatton, E. and A. Lwoff, 1930. Imprégnation par diffusion 
argentique de l'infraciliature des ciliés marins et d'eau douce, après fixation cytologique et sans dessication. C. R. Soc. Biol., 104: 834-836.

Chatton, E. and A. Lwoff, 1935. Les Ciliés Apostomes I. Aperçu historique et généra: étude monographique des generes et des espèces. Arch. Zool. Exp. Gén., 77: 1-453.

Corliss, J.O., 1953. Silver impregnation of ciliated protozoa by the Chatton-Lwoff technic. Stain Technol., 28: 97-100.

Curds, C.R., 1974. Descriptions of three species of Euplotes (Protozoa: Ciliatea). Bull. Br. Mus., 27: 113-125.

Curds, C.R., 1975. A guide to the species of the genus Euplotes (Hypotrichida, Ciliatea). Bull. Br. Mus., 28: 1-63.

Foissner, W., 1991. Basic light and scanning electron microscopic methods for taxonomic studies of ciliated protozoa. Eur. J. Protistol., 27: 313-330.

Gates, M.A., 1978. Morphometric variation in the Hypotrich ciliate genus Euplotes. J. Protozool., 25: 338-350.

Gates, M.A. and C.R. Curds, 1979. The dargyrome of the genus Euplotes (Hypotrichida, Ciliophora). Bull. Br. Mus., 35: 127-134.

Jo, J.O. and M.K. Shin, 2003. Redescription of newly recorded ciliate, Euplotes muscorum (Ciliophora: Polyhymenophora: Hypotrichida) and comparison with related species from Korea. Korean J. Syst. Zool., 19: 227-235.

Kahl, A., 1932. Urtiere oder Protozoa I: Wimpertiere oder Ciliata (Infusoria), eine Bearbietung der freilebenden und ectocommensalen Infusorien der Erde, unter Ausschluss der marinen Tintinnidae. 3. Spirotricha. Die Tierwelt Deutschands, 25: 399-650.

Kim, S.J. and G.S. Min, 2009a. Optimization of DNA extraction from a single living ciliate for stable and repetitive PCR amplification. Anim. Cells Syst., 13: 351-356.

Kim, S.J. and G.S. Min, 2009b. Taxonomic study of poolyknown marine pleurostomatid ciliates of Litonotus paracygnus and L. pictus (Ciliophora: Pleurostomatida) from Korea. Korean J. Syst. Zool., 25: 167-178.

Kwon, C.B. and M.K. Shin, 2006. Redescription of previously unknown euplotine ciliates, Euplotes charon and Diophrys oligothrix (Ciliophora: Spirotrichea: Euplotida), from Korea. Korean J. Syst. Zool., 22: 29-35.

Kwon, C.B., Y.S. Kang and M.K. Shin, 2007. Two newly recorded estuarine ciliates, Euplotes vannus and E. parawoodruffi (Ciliophora: Spirotrichea: Euplotida) from Korea. Korean J. Syst. Zool., 23: 229-235.

Lynn, D.H. and E.B. Small, 2002. Phylum Ciliophora, Doflein, 1901. In An Illustrated Guide to the Protozoa Lee, Leedale and Bradbury, eds., Volume 1. Wiley-Blackwell, Lawrence, Kansas, pp. 371-656.

Petroni, G., F. Dini, F. Verni and G. Rosati, 2002. A molecular approach to the tangled intrageneric relationships underlying phylogeny in Euplotes (Ciliophora, Spirotrichea). Mol. Phylogenet. Evol., 22: 118-130.

Schwarz, M.V.J., A. Zuendorf and T. Stoeck, 2007. Morphology, ultrastructure, molecular phylogeny, and autecology of $\mathrm{Eu}$ plotes elegans Kahl, 1932 (Hypotrichida; Euplotidae) isolated from the anoxic Mariager Fjord, Denmark. J. Eukaryot. Microbiol., 54: 125-136.

Shin, M.K. and H.S. Kim, 1988. Several hypotrichous ciliates inbabiting the Han river in Seoul. Korean J. Syst. Zool., 2: 67-85.

Shin, M.K., H.S. Kim and W. Kim, 1992. New records of hypotrichs from Korea (Protozoa, Ciliophora, Hypotrichida). Korean J. Syst. Zool., 3: 15-22.

Shin, M.K. and W. Kim, 1995. Hypotrichs (Ciliophora, Hypotrichida) from Ullung Island, Korea. Korean J. Zool., 38: 160166.

Song, W., A. Warren and X. Hu, 2009. Free-living ciliates in the Bohai and Yellow Seas, China. Science Press, Beijing, pp. 1-518.

Song, W. and N. Wilbert, 1997. Morphological investigations on some free living ciliates (Protozoa, Ciliophora) from China Sea with description of a new hypotrichous genus, Hemigastrostyla nov. gen. Arch. Protistenkunde, 148: 413444.

Tamura, K., J. Dudley, M. Nei and S. Kumar, 2007. MEGA4: molecular evolutionary genetics analysis (MEGA) software version 4.0. Mol. Biol. Evol., 24: 1596-1599.

Tuffrau, M., 1960. Révision du genre Euplotes, fondée sur la comparaison des structures superficielles. Hydrobiologia, 15: 1-77.

Xu, H., G.S. Min, J.K. Choi, S.J. Kim, J.H. Jung and B.J. Lim, 2009. An approach to analyses of periphytic ciliate communities for monitoring water quality using a modified artificial substrate in Korean coastal waters. J. Mar. Biolog. Assoc. U.K., 89: 669-679.

Yi, Z.Z., W.B. Song, J.C. Clamp, Z.G. Chen, S. Gao and Q.Q. Zhang, 2009. Reconsideration of systematic relationships within the order Euplotida (Protista, Ciliophora) using new sequences of the gene coding for small-subunit rRNA and testing the use of combined data sets to construct phylogenies of the Diophrys-complex. Mol. Phylogenet. Evol., 50: 599-607.

Yocom, H.B., 1930. Two new species of Euplotes from Puget Sound. Puget Sound Mar. Biol. Sta., 7: 241-248.

Received February 24, 2010 Accepted March 11, 2010 